KONSTRUKTIVISME, Vol. 10, No. 2, Juli 2018

p-ISSN: 1979-9438; e-ISSN: 2442-2355

FKIP Universitas Islam Balitar, Blitar

Http://konstruktivisme.unisbablitar.ejournal.web.id; Email: konunisba@gmail.com

\title{
REORIENTASI PENDIDIKAN PESANTREN \\ (TELAAH ATAS TUJUAN PENDIDIKAN ISLAM DI PONDOK PESANTREN AL-ISLAM JORESAN MLARAK PONOROGO)
}

\author{
Rohmad Arkam \\ Dosen STKIP PGRI Ponorogo \\ Email: arkamrohmad.ra.@gmail.com
}

ABSTRAK:

Penelitian ini bertujuan untuk menelaah reorientasi pendiidkan pesantren atas tujuan pendidikan Islam di pondok pesantren Al-Islam Joresan Mlarak Ponorogo. Penelitian ini termasuk penelitian deskriptif, study kasus di pondok pesantren Al-Islam Joresan Mlarak Ponorogo. Dalam pengumpulan data, penulis menggunakan metode wawancara, observasi, dan dokumentasi sebagai teknik pengumpulan datanya. teknik yang dipilih dalam analisis data adalah reduksi data, display data dan pengambilan kesimpulan atau verifikasi. Dari hasil penelitian yang telah dilakukan ditemukan, bahwa (1) Latar belakang rorientasi pendidikan Islam yang dilakukan pondok pesantren Al-Islam, menunjukan bahwa pondok pesantren Al-Islam tidak acuh terhadap tantangan perubahan sosial, melibatkan diri dalam perubahan sosial dan menjadikan dirinya sebagai pusat perubahan sosial itu sendiri (2) Arah pengembangan pendidikan Islam di pondok pesantren Al-Islam Joresan Mlarak Ponorogo adalah sesuai dengan Model neo modernis yaitu metode yang berupaya memahami ajaran-ajaran dan nilai-nilai mendasar yang terkandung dalam al-Qur'an dan al-Sunnah alShahihah dengan mengikut sertakan dan mempertimbangkan khazanah intelektual muslim klasik (3) Bentuk reorientasi di pondok pesantren Al-Islam adalah pengembangan kurikulum, pengembangan evaluasi dan kelembagaan.

Kata Kunci: reorientasi, pesantren, pendidikan Islam

\section{ABSTRACT:}

This research is aiming at examining the reorientation of Islamic boarding schools for the purpose of Islamic education in the Al-Islam Joresan Mlarak Ponorogo Islamic boarding school. This study included as a descriptive research, a case study was in the Al-Islam Joresan Mlarak Ponorogo boarding school. In collecting data, the writer used methods of interview, observation, and documentation. The techniques of analyzing data are reduction data, displaying data, and drawing 
Rohmad Arkam. 2018. Reorientasi Pendidikan Pesantren (Telaah atas Tujuan Pendidikan Islam di Pondok Pesantren Al-Islam Joresan Mlarak Ponorogo).

Konstruktivisme, 10 (2): 239-247

conclusion or verification. Based on the result of the research, it was found that (1) background of reorientation of Islamic education in Al Islam Islamic boarding school conveys that it is indifferent toward the challenges of social change, participating themselves in social changes and playing role as an agent of social change (2) the aim of development of Islamic education at Islamic boarding school Al Islam Josaren Mlarak Ponorogo is in accordance with the Neo-Modernism model, it is a method trying to understand the basic thoughts and values contained in the Al Qur'an and As Sunnah by implicating and considering the treasures of classical intellectual Muslims. (3)the design of reorientation in Al Islam Islamic boarding school is a curriculum development, evaluation and institutionaldevelopment.

Keywords: reorientation, Islamic boarding school, Islamic education.

\section{PENDAHULUAN}

Pesantren sebagai lembaga keagamaan merupakan realitas yang tidak dapat dipungkiri. Sepanjang sejarah yang dilaluinya, pesantren terus menekuni pendidikan dan menjadikannya sebagai fokus kegiatannya (Abdul A'la 2006:15). Dalam struktur pendidikan nasional, pondok pesantren merupakan mata rantai yang sangat penting. Hal ini dikarenakan pondok pesantren dengan tujuan pokoknya yaitu tafaqquh fi al-din (pendalaman pengetahuan tentang agama) dan tarbiyah al- akhlaq (pembentukan kepribadian/budi pekerti) telah secara signifikan ikut andil dalam upaya ikut mencerdaskan kehidupan bangsa.

Namun, kini reputasi pesantren terkesan berada di menara gading, elitis, jauh dari realitas social, problematika sosialisasi dan aktualisasi ini ditambah lagi dengan problem keilmuan, yaitu terjadi kesenjangan, keterasingan, dan pembedaan antara keilmuan pesantren dengan dunia modern. Dikarenakan pesantren hanya berorientasi pada ilmu agama dan pembinaan akhlak saja. Sehingga terkadang lulusan pesantren kalah bersaing atau tidak siap berkompetisi dengan lulusan umum terutama dalam profesionalisme di dunia kerja.

Oleh karena itu di tengah kompetisi sistem pendidikan saat ini, pesantren sebagai lembaga pendidikan tertua yang masih bertahan hingga kini tentu saja harus disadari bahwa pengiatan pesantren yang hanya berorientasi pada wilayah keagamaan (tafaqquh fi al-din) tidak lagi memadai. Maka pesantren harus proaktif dan memberikan ruang bagi pembenahan dan pembaharuan sistem pendidikan pesantren dengan senantiasa harus selalu apresiatif sekaligus selektif dalam menyikapi dan merespons perkembangan dan pragmatisme budaya yang kian menggejala, sehingga alumni pesantren bisa menjadi agent of change di tengah mansyarakat yang produktif, egaliter, 
Rohmad Arkam. 2018. Reorientasi Pendidikan Pesantren (Telaah atas Tujuan Pendidikan Islam di Pondok Pesantren Al-Islam Joresan Mlarak Ponorogo).

Konstruktivisme, 10 (2): 239-247

serta terbuka terhadap realitas perubahan sosial, tanpa kehilangan nilai transendentalnya.

Menurut Abdul A'la (2005:9), pesantren, dengan teologi yang dianutnya hingga kini, ditantang untuk menghadapi globalisasi secara aktif dan bijak. Pesantren harus mampu menjadi solusi yang benar-benar mencerahkan sehingga pada satu sisi dapat menumbuh kembangkan kaum santri yang memiliki wawasan luas yang tidak gampang menghadapi modernitas dan sekaligus tidak kehilangan, dan jatidirinya, dan, pada sisi lain dapat mengantarkan masyarakat menjadi komonitas yang menyadari tentang persoaalan yang dihadapi dan mampu mengatasi dengan penuh kemandirian dan keadaban.

Pondok pesantren Al-Islam Joresan Mlarak Ponorogo adalah salah satu lembaga pendidikan Islam yang mempunyai mempunyai keunikan dan karismatik tersendiri yang mem bedakan dengan lembaga pendidikan Islam lain di daerah sekitarnya, yakni; merupakan pondok pesantren yang menerapkan tujuan pendidikannya tidak hanya terfokus pada tafaqquh fi al-din (pendalaman pengetahuan tentang agama) dan tarbiyah al-akhlaq (pembentukan kepribadian/budi pekerti) akan tetapi mencoba mensinergikan hal tersebut dengan perkembangan zaman dengan adanya keseimbangan kecerdasan, sikap dan keterampilan; kemampuan berkomunikasi dan berinteraksi dengan masyarakat secara luas.

Berdasarkan penjajakan di lapangan, bahwasanya pondok pesantren Al-Islam Joresan Mlarak Ponorogo dalam reorientasi tujuan pendidikanya dengan menyeimbangkan pelajaran yang bersifat umum dengan agama juga dibukanya sekolahan kejuruan selain itu juga memberikan bekal life skill sebagai bekal untuk dapat digunakan dalam menghadapi berbagai perubahan dan tantangan masa depan. Berangkat dari hal tersebut maka peneliti mengadakan sebuah penelitian dengan sebuah judul reorientasi pendidikan pesantren (telaah atas tujuan pendidikan Islam di pondok pesantren Al-Islam Joresan Mlarak Ponorogo).

\section{METODE PENELITIAN Jenis Penelitian}

Jenis penelitian yang digunakan dalam penelitian ini adalah studi kasus penelitian lapangan (field research) atau dapat juga dianggap sebagai pendekatan luas dalam penelitian kualitatif (Moleong, 2000:3)

\section{Sumber data}

Sumber data dalam penelitian kualitatif adalah kata-kata dan tindakan, selebihnya adalah data tambahan. (Moleong, 2000:112) Pada penelitian ini yang nantinya menjadi sumber data adalah informan yang jumlahnya tidak terbatas karena sifat penelitian ini adalah kualitatif. Yang sekurang-kurangnya 
Rohmad Arkam. 2018. Reorientasi Pendidikan Pesantren (Telaah atas Tujuan Pendidikan Islam di Pondok Pesantren Al-Islam Joresan Mlarak Ponorogo).

Konstruktivisme, 10 (2): 239-247

sebanyak lima informan yang terdiri dari: direktur pondok, kepala sekolah MTS, MA dan SMK, serta beberapa guru. Sedangkan sumber dan data tertulis, foto, serta hal-hal lain yang diperlukan merupakan pelengkap dari penggunaan metode wawancara dan observasi.

\section{Teknik Pengumpulan Data}

Teknik pengumpulan data dalam penelitian ini menggunakan wawancara, observasi dan dokumentasi. Sebab bagi peneliti kualitatif, fenomena dapat dimengerti maknanya dengan baik, apabila dilakukan interaksi dengan subyek melalui wawancara mendalam, dan observasi pada latar dimana fenomena tersebut berlangsung.

\section{HASIL DAN PEMBAHASAN \\ Latar Belakang Reorientasi Pendidikan Islam Di Pondok Pesantren Al- Islam Joresan Mlarak Ponorogo.}

Mencermati apa yang melatar belakangi terjadinya reorientasi pendidikan Islam di pondok pesantren Al-Islam, yaitu dilatar belakangi dengan adanya tuntutan yang mengharuskan adanya ijazah yang mendapat pengakuan pemerintah untuk meneruskan ke jenjang yang lebih tinggi dan juga tuntutan bagi dunia kerja baik pemerintahan maupun swasta.

Latar belakang tersebut dikaji dengan dimensi filosofi dari masingmasing institusi kependidikan dalam menghadapi tantangan terhadap pendidikan, ada beberapa sikap yang harus dipegang yaitu:

1. Tidak acuh terhadap tantangan perubahan sosial.

2. Mengakui adanya perubahan sosial, tetapi menyerahakan pemecahan kepada orang lain.

3. Mengidentifikasi perubahan dan berpartisipasi dalam perubahan itu.

4. Melibatkan diri dalam perubahan sosial dan menjadikan dirinya sebagai pusat perubahan sosial itu. (Muhammad Arifin,1995:48)

Dari penjelasaan di atas dengan latar belakang reorientasi pendidikan Islam yang dilakukan pondok pesantren Al-Islam, menunjukan bahwa pondok pesantren Al-Islam tidak acuh terhadap tantangan perubahan sosial, melibatkan diri dalam perubahan sosial dan menjadikan dirinya sebagai pusat perubahan sosial itu sendiri, hal ini bisa dilihat dengan jelas dilapangan bahwa pondok pesantren Al-Islam yang awalnya menyelengarakan pengajaranya dengan hanya berorientasi pada pendidikan agama kemudian mengadakan pengembangan arah tujuannya dengan adanya keseimbangn antar penanaman ilmu-ilmu agama dengan ilmu-ilmu yang bersifat umum.

Pengembangan arah tujuan pendidikan di pondok pesantren Al-Islam ini dengan direalisasikanya pembukaan program formal Madrasah Tsanawiyah (MTS), Madrasah Aliyah (MA) dan Sekolah Menengah Kejuruan (SMK) dengan mewujudkan pendidikan yang tidak hanya hasil lulusanya diukur dari pengakuan dari kiayinya saja akan tetapi ada sebuah bukti berupa 
Rohmad Arkam. 2018. Reorientasi Pendidikan Pesantren (Telaah atas Tujuan Pendidikan Islam di Pondok Pesantren Al-Islam Joresan Mlarak Ponorogo).

Konstruktivisme, 10 (2): 239-247

ijazah yang dilegalkan oleh pemerintah melaluli ujian nasional (UN) dengan tujuan menaggapi permintaan masyarakat khususnya dunia kerja.

\section{Arah Reorientasi Pendidikan Islam di Pondok Pesantren Al-Islam Joresan Mlarak Ponorogo.}

Arah reorientasi pendidikan Islam di pondok pesantren Al-Islam Joresan Mlarak Ponorogo yaitu adanya perpaduan ilmu agama dan pengetahuan umum dengan dengan tetap mengajarkan nilai lama yang ada yaitu metode salaf dengan ciri khas mengajarkan kitab kuning.

Arah reorientasi ini apabila dikaji dengan kajian pemikiran (filsafat) pendidikan Islam dalam menjawab tantangan perubahan zaman dan modernisasi yaitu sesuai dengan model neo modernis, menurut Muhaimin (2004:42) metode neo modernis yaitu metode yang berupaya memahami ajaran-ajaran dan nilai-nilai mendasar yang terkandung dalam al-Qur'an dan al-Sunnah dengan mengikut sertakan dan mempertimbangkan khazanah intelektual muslim klasik serta mencermati kesulitan-kesulitan dan kemudahan-kemudahan yang ditawarkan oleh dunia teknologi modern. Jargon yang sering dikumandangkan adalah "al-Muhafadhotu 'ala al-Qodim al-Shalih wa al-Akhzu bi al-Jadid al-Ashlah", yakni memelihara hal-hal yang baik yang telah ada sambil mengembangkan nilai-nilai baru yang lebih baik.

Dilihat dari kalimat al-Muhafadhotu 'ala al-Qodim al-Shalih yang mengaris bawahi adanya unsur perenialism, yakni sikap regresif, yakni jiwa yang yang menguasai nilai-nilai llahi dan konserfatif, yakni mempertahankan nilai-nilai insani yang telah ada yang telah dibangun serta dikembangkan oleh pemikir dan masyarakat terdahulu.

Sikap regresif pondok pesantren Al-Islam dapat dilihat dari praktek ibadah santri melalui sholat wajib maupun sholat sunnah berjama'ah untuk menumbuhkan sikap dan prilaku yang selalu ingat dan sesuai dengan aturanaturan Tuhan. Sedangkan sikap konserfatif pondok pesantren Al-Islam ini dapat dibuktikan dari kurikulum yang ada di pondok pesantren Al-Islam yang tetap menggunakan metode salaf dengan cirri khasnya pengajaran kitab kuning disemua jenjang pendidikan di pondok pesantren Al-Islam baik Madrasah Tsanawiyah (MTS), Madrasah Aliyah (MA) maupun Sekolah Menengah Kejuruan (SMK). Kitab yang digunkan untuk metode salaf adalah pelajaran fiqh menggunakan kitab Takrib, pelajaran akidah mengunakan kitab Kifayatul 'awam dan pelajaran akhlak mengunakan kitab Ta'limu Muta'alim.

Dikaji dari kalimat al-Akhzu bi al-Jadid al-Ashlah, yakni, mencari alternatif yang terbaik dan juga menunjukkan adanya sikap dinamis dan progresif serta sifat rekonstruktif walaupun tidak bersifat radikal hal ini dapat dibuktikan deng an adanya pelajaran-pelajaran umum yang diselengarakan di pondok pesantren Al-Islam juga membuka sekolah kejuruan selain itu juga 
Rohmad Arkam. 2018. Reorientasi Pendidikan Pesantren (Telaah atas Tujuan Pendidikan Islam di Pondok Pesantren Al-Islam Joresan Mlarak Ponorogo).

Konstruktivisme, 10 (2): 239-247

adanya sarana prasarana penunjang mengunkan peralatan yang sesuai dengan tuntutan zaman

\section{Bentuk Reorientasi Pendidikan Islam di Pondok Pesantren Al-Islam Joresan Mlarak Ponorogo.}

Bentuk reorientasi di pondok pesantren Al-Islam adalah dengan diselenggarakanya jenjang pendidikan formal MTS, MA (IPA, IPS dan Keagamaan) dan SMK (teknik komputer dan jaringan) dengan tetap menjaga nilai lama yang ada di pondok ini yaitu metodhe salaf dengan ciri khas mengajarkan kitab kuning. Reorientasi pendidikan Islam di pondok pesantren Al-Islam tersebut dilihat dengan teori bentuk pengembangan dalam pendikan pesantren yaitu:

1. Pengembangan kurikulum yang meliputi beberapa unsur diantaranya adalah: Pegembangan metode pembelajaran yaitu, pola pembelajaran dari pola sorogan berubah menjadi sistem madrasi atau klasikal. Tidak hanya itu, beberapa pendidikan ketrampilan juga mulai masuk kedunia pesantren. Pembelajaran ketrampilan, seperti bertani, berternak, kerajinan tangan mulai akrab di kehidupan san tri sehari-hari. Ini dimaksut untuk mengembangkan wawasan atau orientasi santri dari pandangan hidup yang terlalu berorientasi ukhrowi, supaya menjadi seimbang dengan kehidupan duniawi.

2. Pengembangan evaluasi, yaitu kemampuan santri biasanya dievalusi dengan keberhasilanya mengajarkan kitab kepada orang lain. Jika audiensinya merasa puas, maka hal itu santri nyang bersangkutan dinilai telah lulus. Legalisasi kelulusannya adalah restu kiai bahwa santri tersebut diizinkan pindah mempelajari kitab lain yang lebih tinggi tingkatanya dan boleh mengjarkan kitab yang dikuasinya kepada orang lain. Pesantren yang telah mengadopsi pembaharuan kurikulum, baik yang mengacu pada departemen agama maupun departemen pendiidkan Nasional jelas telah meninggalkan model evaluasi seperti tersebut tadi. Pesantren model madrasi pada umumnya, yaitu mengunakan ujian resmi dengan memberikan angka-angka kelulusan serta tanda kelulusan seperti ijazah.

3. Pegembangan materi/pengetahuan (knowledge) yaitu, pada umumnya pesantren sebagai lembaga pendidikan Islam, materi pembelajarannya lebih mengutamkan pelajaran agama Islam yang bersumber dari kitabkitab klasik, seperti Tauhid, Hadits, Tafsir, Fiqh dan sejenisnya. Kurikulumnya didasarkan pada tingkat awal, menengah, dan lanjut. Dalam selanjutnya, setiap pesantren telah melakukan pembaharuan kurikulum dengan memasukkan pendidikan umum dalam kurikulum pesantren. Sifatnya berfariasi, ada pesantren yang memasukan pendidikan agama 30\% dan $70 \%$ umum; ada pula yang sebaliknya, 
Rohmad Arkam. 2018. Reorientasi Pendidikan Pesantren (Telaah atas Tujuan Pendidikan Islam di Pondok Pesantren Al-Islam Joresan Mlarak Ponorogo).

Konstruktivisme, 10 (2): 239-247

yaitu $80 \%$ agama dan sisianya adalah pelajaran umum. Amiruddin Nahrawi, 1994: 31)

4. Pengembangan kelembagaan, yaitu pengembangan kelembagan ini lembaga pendidikan Islam dapat membuka program studi yang bervariasi seperti, program studi IImu Alam, IImu Sosial, IImu Bahasa, Madrasah Aliyah Keagamaan (MAK), dan madrasah aliyah kejuruan (MKAJ). Mengingat luasnya lapangan kerja di era pasar bebas, MKAJ dapat pula membuka prodi yang bervariasi sesuai dengan kebutuhan masyarakat.( Ramayulis, 2002:343)

Dilihat dilihat dengan teori bentuk pengembangan dalam pendikan pesantren tersebut, dapat digaris bawahi bahwa bentuk reorientasi yang dilakukan pondok pesantren Al-Islam Joresan Mlarak Ponorogo adalah bentuk pengembangan kurikulum dan pengembangan kelembagaan. Bentuk pengembangan kurikulum dapat dibuktikan pertama dengan pengembangan metode, hal ini dapat dilihat dari proses belajar menegajar yang pada awalnya dengan system sorogan dan berada mushola sekarang sudah mengunakan metode klasikal dan berada di kelas selain itu di pondok pesantren Al-Islam ada pembekalan life skill dengan program keputrian yang di dalamnya ada kursus menjahit untuk santriwati.

Kedua, pengembangan evaluasi di pondok pesantren Al-Islam Joresan Mlarak Ponorogo ini dapat dilihat dari ujian resmi yang dilakukan oleh setiap jenjang yang ada di pondok pesantren Al-Islam baik Madrasah Tsanawiyah (MTS), Madrasah Aliyah (MA) dan Sekolah Kejuruan (SMK) ujian dilakukan di pertengahan semester, akhir semester, ujian syafahi (lesan) maupun ujian nasional (UN) untuk kelas sembilan dan kelas dua belas. Semua ujian tersebut mempunyai setandar yang digunkan untuk kenaikan kelas maupun kelulusan dan pemberian ijazah untuk kelas sembilan dan dua belas yang ikut ujian nasional (UN).

Ketiga, pengembangan materi dapat dibuktikan yang awalnya pondok pesantren Al-Islam hanya memberikan materi ajarnya kitab-kitab klasik, seperti Tauhid, Hadits, Tafsir, Fiqh kemudian ditambah dengan pelajaranpelajaran umum seperti bahasa Ingris, matematika, IPA, IPS dan sebagainya. Selain pengembangan kurikulum yang dibuktikan adanya pengembangan unsur-unsurnya seperti metode, evaluasi dan materi seperti yang dijelaskan di atas bentuk reorientasi di pondok Al-Islam adalah adanya pengembangan kelembagaan hal ini dapat dibuktikan dengan adanya jenjang formal Madrasah Tsanawiyah (MTS), Madrasah Aliyah (MA) dan Sekolah Kejuruan (SMK) jurusan teknik computer dan jaringan.

\section{SIMPULAN}

Berdasarkan hasil penelitian dan pembahasan yang telah diuraikan, maka dapat disimpulkan sebagai berikut: 
Rohmad Arkam. 2018. Reorientasi Pendidikan Pesantren (Telaah atas Tujuan Pendidikan Islam di Pondok Pesantren Al-Islam Joresan Mlarak Ponorogo).

Konstruktivisme, 10 (2): 239-247

1. Latar belakang reorientasi pendidikan Islam yang dilakukan pondok pesantren Al-Islam, menunjukan bahwa pondok pesantren Al-Islam melibatkan diri dalam perubahan sosial dan menjadikan dirinya sebagai pusat perubahan sosial itu sendiri

2. Arah pengembangan pendidikan Islam di pondok pesantren Al-Islam Joresan Mlarak Ponorogo adalah sesuai dengan Model neo modernis yaitu metode yang berupaya memahami ajaran-ajaran dan nilai-nilai mendasar yang terkandung dalam al-Qur'an dan al-Sunnah alShahihah dengan mengikut sertakan dan mempertimbangkan khazanah intelektual muslim klasik.

Bentuk reorientasi di pondok pesantren Al-Islam adalah pengembangan kurikulum, pengembangan evaluasi dan kelembagaan.

\section{SARAN}

Berdasarkan keseluruhan hasil tersebut di atas dari hal-hal yang telah diteliti di pondok pesantren Al-Islam Joresan Mlarak Ponorogo, maka dapat dikemukakan saran-saran sebagai berikut:

1. Diharapkan bagi peneliti dan teoritikus pendidikan agar bisa mengkaji dan memberikan kontribusi pemikiran terhadap reorientasi pendidikan pesantren untuk memajukan pendidikan yang telah ada.

2. Bagi lembaga supaya lebih memperhatikan penghambat-penghambat proses reorientasi agar kedepanya pondok pesantren Al-Islam benarbenar mampu dan siap menghadapi tuntutan peradaban zaman.

3. Bagi praktisi pendidikan dapat mengambil segi-segi positif dari arah dan bentuk-bentuk pengembangan pendidikan pesantren

\section{DAFTAR RUJUKAN}

A'la, Abdul. Pembaharuan Pesantren, Yogyakarta: Lkis, 2006.

Arif, Mahmud. Pendidikan Islam Transformatif, Yogyakarta: Lkis, 2008

Azra, Azyumardi. Buku Teks Pendidikan Agama Islam Pada Perguruan Tinggi Umum, Jakarta; Departemen agama RI, 2003.

Pendidikan Islam, Tradisi dan Modernisasi Menuju Millenium Baru, Jakarta: Logos, 2000.

An-nahlawi, Abdurahman, Pendidikan Islam di Rumah, Sekolah dan Masyarakat, Jakarta: Gema Insani, 2004.

Dhofier, Zamakhsyari, Tradisi Pesantren, LP3S:Jakarta, 1982. 
Rohmad Arkam. 2018. Reorientasi Pendidikan Pesantren (Telaah atas Tujuan Pendidikan Islam di Pondok Pesantren Al-Islam Joresan Mlarak Ponorogo).

Konstruktivisme, 10 (2): 239-247

Moleong, Lexy J Metodologi Penelitian Kualitatif, Bandung: PT. Remaja Rosdakarya, 2000.

Muhaimin, Wacana Pengembangan Pendidikan Islam, Surabaya: Pustaka Pelajar, 2004.

Nizar, Samsul, Filsafat Pendidikan Islam, Pendekatan Historis, Teoristis dan Praktis, Jakarta, Ciputat Pers, 2002.

Nahrawi, Amiruddin, Pembharuan Pendidikan Pesantren, Jogjakarta: Gama media, 1994

Yunus, Mahmud. Ushulu At-Tarbiyatu Watta'lim, Ponorogo: PM Gontor, 2011.

Yasmani, Modernisasi Pesantren; Kritik Nurcholis Majid Terhadap Pendidikan Islam Tradisional, Ciputat Press: Ciputat, 2002.

Zuhairini, Filsafat Pendidikan Islam, Surabaya: Bumi Aksara, 1994. 